\title{
Reproductive biology of the ascidians Styela rustica and Halocynthia pyriformis from Kongsfjorden, Svalbard, Arctic
}

\author{
Luciana Ferrero $^{1} \cdot$ Natalia Servetto $^{1,2} \cdot$ Jürgen Laudien $^{3} \cdot$ Ricardo Sahade $^{1,2}$
}

Received: 19 March 2019 / Revised: 21 August 2019 / Accepted: 23 August 2019 / Published online: 5 September 2019

(c) Springer-Verlag GmbH Germany, part of Springer Nature 2019

\begin{abstract}
Ascidians are abundant and well-represented members of worldwide benthic communities, including Antarctica and the Arctic. These organisms exhibit different reproductive patterns usually related to a latitudinal gradient, as do many marine invertebrate species. Reproductive seasonality varies from one or two annual peaks in cold and temperate water species to continuous reproduction throughout the year in warm water species. Styela rustica (Linnaeus 1767) and Halocynthia pyriformis (Rathke 1806) are solitary species with external fertilization and a wide distribution range, from the North Atlantic to the Arctic. The reproductive patterns of these two species were assessed for Arctic populations by year-round sampling and structural analysis of the gonads. Both species are hermaphrodites and showed marked seasonality in oocyte maturity and spawning; S. rustica peaked during the boreal summer and $H$. pyriformis in late spring. The two species also showed marked differences in mature oocyte sizes: $H$. pyriformis almost doubled those of $S$. rustica and, while spermatocytes of $H$. pyriformis were mature year-round, the maturity of male and female gametes was synchronized in $S$. rustica. The species thus showed an annual reproductive cycle coupled with a higher production period in the ecosystem, but also exhibited different strategies developed under the same environmental pressures.
\end{abstract}

Keywords Polar ecosystems $\cdot$ Tunicates $\cdot$ Life cycles $\cdot$ Reproductive ecology

\section{Introduction}

Electronic supplementary material The online version of this article (https://doi.org/10.1007/s00300-019-02570-9) contains supplementary material, which is available to authorized users.

Luciana Ferrero

ferreroluciana.lf@gmail.com

Natalia Servetto

servetto.natalia@conicet.gov.ar

Ricardo Sahade

rsahade@unc.edu.ar

1 Ecología Marina, Facultad de Ciencias Exactas, Físicas Y Naturales, Universidad Nacional de Córdoba, Córdoba, Argentina

2 Consejo Nacional de Investigaciones Científicas Y Técnicas (CONICET), Instituto de Diversidad Y Ecología Animal (IDEA), Ecosistemas Marinos Polares, Av. Vélez Sársfield 299, X5000JJC Córdoba, Argentina

3 Alfred Wegener Institute Helmholtz Centre for Polar and Marine Research, Am AltenHafen 26, 27568 Bremerhaven, Germany
Ascidians are exclusively marine species with a cosmopolitan distribution from rocky shores to the muddy bottoms of abyssal plains. They are sessile suspension feeders, exhibit solitary or colonial growth, and are important members of many benthic communities (e.g., Shenkar 2012).

Ascidians show different reproductive strategies, but with some generalized and fixed traits such as hermaphroditism and lecithotrophic larvae. To avoid self-fertilization, some species are protandrous, and others present a blocking system in the oocyte membranes (Lambert 2009). Solitary ascidians reproduce only sexually, and most of them are oviparous, releasing their gametes to the environment, where fertilization and larval development takes place. All colonial species and a few solitary ones are brooders; fertilization occurs inside the zooids and mature hatched larvae are then released (Bishop and Ryland 1991).

Reproduction patterns in these groups range from one to two annual peaks in cold and temperate water species, to continuous reproduction throughout the year in warm water or invasive species (Millar 1971; Durante and Sebens 1994; 
Lambert et al. 1995; Shenkar and Loya 2008; Ritzmann et al. 2009; Nagar and Shenkar 2016; Shmuel and Shenkar 2017). Even in some species with a wide latitudinal distribution, reproductive patterns of warm and temperate water populations can clearly differ, e.g., Styela plicata (Sabbadin 1957; Yamaguchi 1975; Sciscioli et al. 1978; Tursi and Matarrese 1981; Pineda et al. 2013).

Many different factors are known to affect the reproductive and developmental processes of ascidians, including photoperiod, temperature, food availability and quality, ocean hydrodynamics, biomechanics, and proximity (Millar 1971; Lambert 2005; Shenkar and Loya 2008; Shmuel and Shenkar 2017). Seasonal changes in the photoperiod may regulate spawning in some species of ascidians (e.g., Ciona intestinalis, Corella eumyota, Corella inflata, S. plicata) and the development of gonads can be correlated with ocean temperature (e.g., Phallusia nigra, Herdmania momus, Halocynthia spinosa) (Lambert and Brandt 1967; West and Lambert 1976; Lambert et al. 1995; Ritzmann et al. 2009; Rius et al. 2009; Pineda et al. 2013; Kanamori et al. 2017; Shmuel and Shenkar 2017; Manríquez et al. 2018).

In polar ecosystems, the temperature is slightly variable, and one of the most important factors driving the biology of most taxa is the markedly seasonal photoperiod (Piepenburg 2005). The growth and reproduction of polar benthic organisms would be expected to be coupled to seasonal primary production especially for primary consumers, while groups of higher trophic levels, such as carnivores, deposit feeders, or necrophagous species, may be decoupled from primary production pulses (Sahade et al. 2004b). However, a different perspective, based on developmental modes and energy requirements of larval stages rather than on adult food necessities, suggests that polar invertebrates with planktotrophic larvae may reproduce coupled to phytoplankton blooms, while brooders or those with lecithotrophic larvae may be decoupled from primary production pulses and reproduce year-round (Pearse et al. 1991). Different strategies have been described for polar marine invertebrates; however, most of the available information is based on Antarctic species (i.e., Clarke 1996; Barnes and Clarke 1998; Chiantore et al. 2002; Orejas et al. 2002; Grange et al. 2004, 2007, 2011; Sahade et al. 2004b; Brockington et al. 2007; Servetto et al. 2013; Servetto and Sahade 2016), and data for Arctic species are scarce (Poltermann et al. 2000; Brandner et al. 2017).

The Arctic Ocean is characterized by low and relatively constant water temperature, close to freezing point, with permanent or long-term ice cover, as well as pronounced seasonality in solar radiation and nutrient availability (Carmack and Wassmann 2006). Based on the geographical location, Kongsfjorden is expected to present these Arctic environmental conditions of low temperature and large seasonal fluctuations in light intensity and sea ice cover. However, at the same time, Kongsfjorden is assumed to have some characteristics of a sub-Arctic fjord, due to the strong influence of the northern branch of the North Atlantic warm current, the West Spitsbergen Current, with temperatures above $4{ }^{\circ} \mathrm{C}$ and salinity of 35 PSU (Loeng 1991; Beszczyjska-Möller et al. 1997; Svendsen et al. 2002; Hegseth and Tverberg 2013; Voronkov et al. 2013).

Common Arctic biota shows a strong affinity with the northern Pacific and the Atlantic and is mainly characterized by low levels of endemism and biodiversity compared to tropical, temperate, and Antarctic ecosystems (Dunton 1992; Gray 2001; McBride et al. 2014; Azovsky et al. 2016). Besides actinians, bryozoans, barnacles, molluscs, and sponges, ascidians belong to the most common solitary taxa of the rocky bottom community of Arctic Kongsfjorden (Sahade et al. 2004a; Beuchel and Gulliksen 2008; Voronkov et al. 2013, 2016; Koziorowska et al. 2017).

The two dominant ascidians in Kongsfjorden, Styela rustica and Halocynthia pyriformis, show a wide distribution range from the north Atlantic to the Arctic, which could indicate that these species disperse efficiently and colonize new habitats. In fact, S. rustica present a distribution range from the Arctic to south of the eastern coast of Canada, while H. pyriformis appear from the Arctic to the northeastern coast of north America (https://obis.org/). This may be related to a more extended larval period spent in the plankton or a high generational turnover coupled with efficient use of suitable habitats resulting in a rapid stepping-stone process. Thus, low population genetic variability would be an expected pattern for these species as for most Arctic species. Coincidentally, these two ascidian species present an overall low genetic structure among the populations studied at Kongsfjorden, suggesting a current gene flow among populations within the fjord. However, $H$. pyriformis exhibited more structured populations than $S$. rustica, and in both cases, there was a correlation between genetic and geographic distances (Demarchi et al. 2008; Demarchi 2013). Therefore, greater knowledge of the reproductive ecology of these species could be useful to understand these patterns.

Knowledge of the reproductive biology of these two ascidian species is scant. In a study at Kristineberg zoological station, western Sweden, Lützen (1960) observed that $S$. rustica has a year-long reproductive cycle, starting during the latter half of January until the end of January of the following year, in which most of the specimens shed their eggs and sperm during the cold season, and these data were also supported by the occurrence of larvae in the plankton. In contrast, in a study in Hvalfjordur, southwest Iceland, Svavarsson (1990) found that H. pyriformis was a seasonal breeder. The first evidence of developing oocytes within the adults was found in late May 1989, when a couple of ascidians had fully developed oocytes. They observed a large number of larvae in June and traces of developing larvae until 
the beginning of August; ascidians spawn mainly in June, during the summer season and the larvae settle in autumn.

This study focused on the reproductive seasonality of the most abundant solitary ascidian species of Kongsfjorden, $S$. rustica (Linnaeus 1767) and H. pyriformis (Rathke 1806) (Sahade et al. 2004a; Laudien and Orchard 2012). To assess whether reproduction is continuous, as expected from the low annual temperature amplitude, or peaks in summer, as expected from the pronounced seasonality of primary production in this ecosystem, and to compare their reproductive strategies and their ecological success.

\section{Materials and methods}

Sampling was conducted in the Arctic glacial Kongsfjorden $\left(79^{\circ} \mathrm{N}, 12^{\circ} \mathrm{E}\right)$, located on the west coast of Spitsbergen (Svalbard), during the summers of 2004 and 2005 (Fig. 1). The fjord is $30 \mathrm{~km}$ long and between 4 and $10 \mathrm{~km}$ wide, with a coverage area of $209 \mathrm{~km}^{2}$, reaching depths of approximately $350 \mathrm{~m}$, with a wide opening to the ocean. This fjord is influenced by both Arctic and Svalbard-Coastal water masses. The outer basin of the fjord is strongly affected by the relatively warm and saline North Atlantic-type waters (temperature $>2{ }^{\circ} \mathrm{C}$, salinity $35 \mathrm{PSU}$ ) transported by the West Spitsbergen Current. The Atlantic influence results in sub-Arctic rather than the Arctic conditions expected by the location at this high latitude. Therefore, Kongsfjorden is a border area between the biogeographic zones of the Atlantic and the
Arctic, hosting a mix of boreal and Arctic flora and fauna (Jørgensen and Gulliksen 2001; Hop et al. 2002; Svendsen et al. 2002; Laudien and Orchard 2012; Nowak et al. 2016; Koziorowska et al. 2017).

To obtain a monthly sample of the study species, and as there are no diving activities during winter, a set-up was developed based on containing individuals in cages that could be retrieved from land (Online Resource 1). During summer 2004, 120 individuals of each of the two ascidian species were collected by SCUBA divers by chiseling colonized substrate pieces. Based on previous examinations of the body size-mature gonad relationships, 10 sexually mature individuals of $S$. rustica and $H$. pyriformis were attached underwater with underwater epoxy (Ivegor Multi Putty, Terneuzen Marine Supplies, Terneuzen, the Netherlands) inside each of 12 stainless steel cages $(45 \mathrm{~cm}$ long $\times 20 \mathrm{~cm}$ wide $\times 20 \mathrm{~cm}$ high) installed at 12 meters depth north of the Ny-Alesund pier. The mesh size of the cages $(25 \mathrm{~mm})$ allowed proper water circulation to ensure close to natural feeding conditions for the animals. Throughout the 2 years (the system was reinstated in 2005 with new individuals collected that year), one cage per month was removed by station personnel by making a hole in the packice and recovering the cage with a rope previously attached to each cage. Some months, cages could not be recovered and were lost due to heavy ice conditions and ice impacts.

Individuals were detached from the respective cage, measured, dissected, and their gonads fixed in Boraxbuffered $3.7 \%$ formaldehyde in seawater for histological a

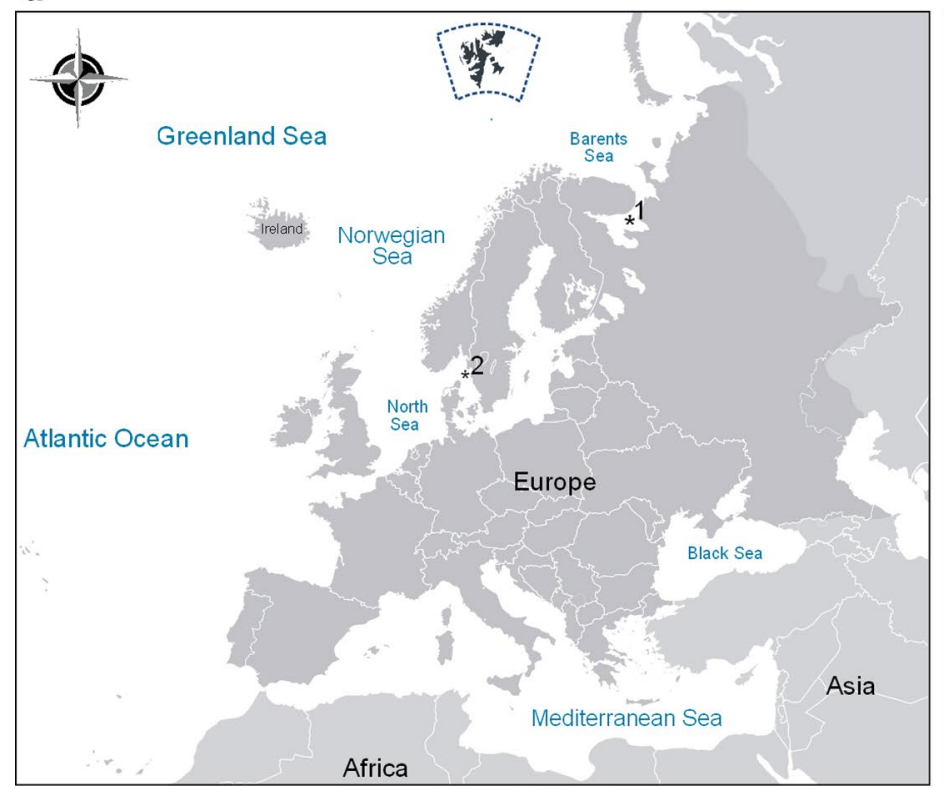

b

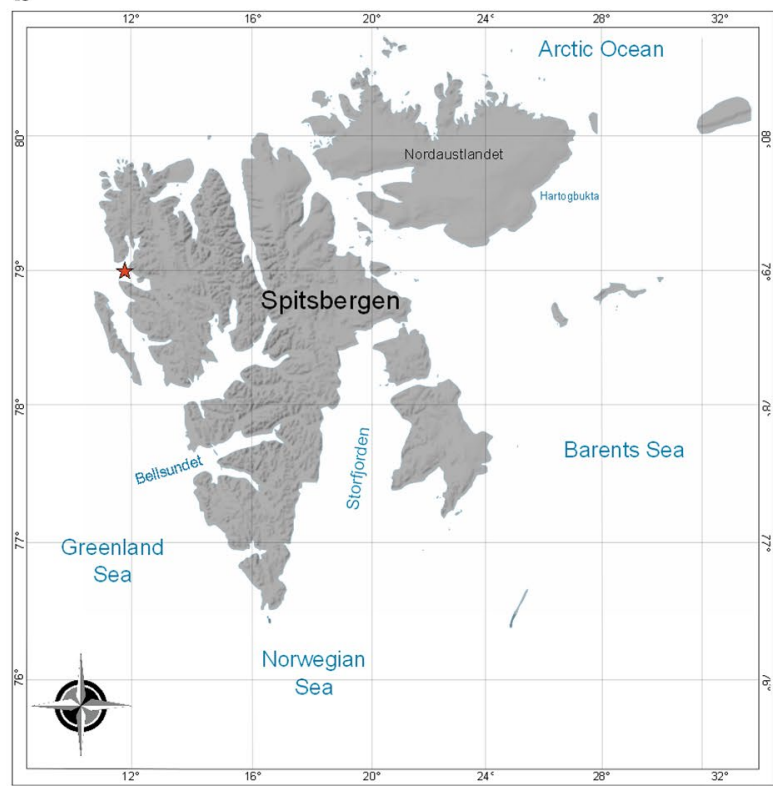

Fig. 1 Map of the study area. a Location of Svalbard archipelago in the Arctic Ocean. $*^{1}$ : White Sea sampling point $\left(66^{\circ} \mathrm{N}, 33^{\circ} \mathrm{E}\right)(\mathrm{Khala}-$ man et al. 2008). $*^{2}$ : Kristineberg, Sweden sampling point $\left(58^{\circ} \mathrm{N}\right.$, $11^{\circ} \mathrm{E}$ ) (Lützen 1960). b Sampling zone Kongsfjorden on the west coast of Spitsbergen (Kongsfjorden inlet) (star) 
analysis. The tissue was embedded in paraffin and considering that the gonads are substantially cylindrical, they were sectioned $(5 \mu \mathrm{m})$ along the two major longitudinal axes to avoid bias due to a possible heterogeneous development in the ovary. Subsequently, they were stained with hematoxylin-eosin following standard procedures (Romeis 1989).

To determine the seasonal pattern of reproduction, an entire section of each gonad was photographed with a digital camera (Nikon E995 3.34 megapixels) under a stereomicroscope (Labomed CZM4). Fifty pictures of each histological section were taken, and thus a single digital gonadal image of each section was reconstructed. The Feret diameter of each oocyte sectioned through its nucleolus was measured using Image J, measuring a total of 100 oocytes whenever possible, and a minimum of 70 . In both species, the oocytes were classified according to their different developmental stages, determined by their size and histological features, into three different classes (Fig. 2), following Becerro and Turon (1992).

The $S$. rustica oocytes were classified as previtellogenic $(<80 \mu \mathrm{m})$-no present yolk granules and the nucleus occupied most of the cytoplasm; vitellogenic $(\geq 80,<160 \mu \mathrm{m})$-yolk granules and some accompanying test cells were present in the cytoplasm; and mature ( $\geq 160 \mu \mathrm{m}$ ) - the cytoplasm continued to accumulate yolk and increase its volume, accompanying test cells and the two layers of follicle cells (internal and external) were observed. Halocynthia pyriformis were classified oocytes as previtellogenic $(<150 \mu \mathrm{m})$-yolk granules were absent in the cytoplasm, and the nucleus occupied most of it; vitellogenic $(\geq 150,<250 \mu \mathrm{m})$ - the cytoplasm continued to accumulate yolk and increase in volume, and accompanying cells and the two layers of follicular cells (internal and external) were present. The maturity of the testes was recorded in both species and classified in three categories
Fig. 2 Gonadal histology of: Styela rustica: a Immature gonad. b Mature gonad. c More details of oocytes, showing $N$ and $n$. And Halocynthia pyriformis: d immature gonad. e Mature gonad. f More details of oocytes, showing nucleus and nucleolus. $P O$ previtellogenic oocytes, $V O$ vitellogenic oocytes, $M O$ mature oocytes, $M F$ male follicles, $F C$ follicular cells, $T C$ test cells, $N$ nucleus, $n$ nucleolus

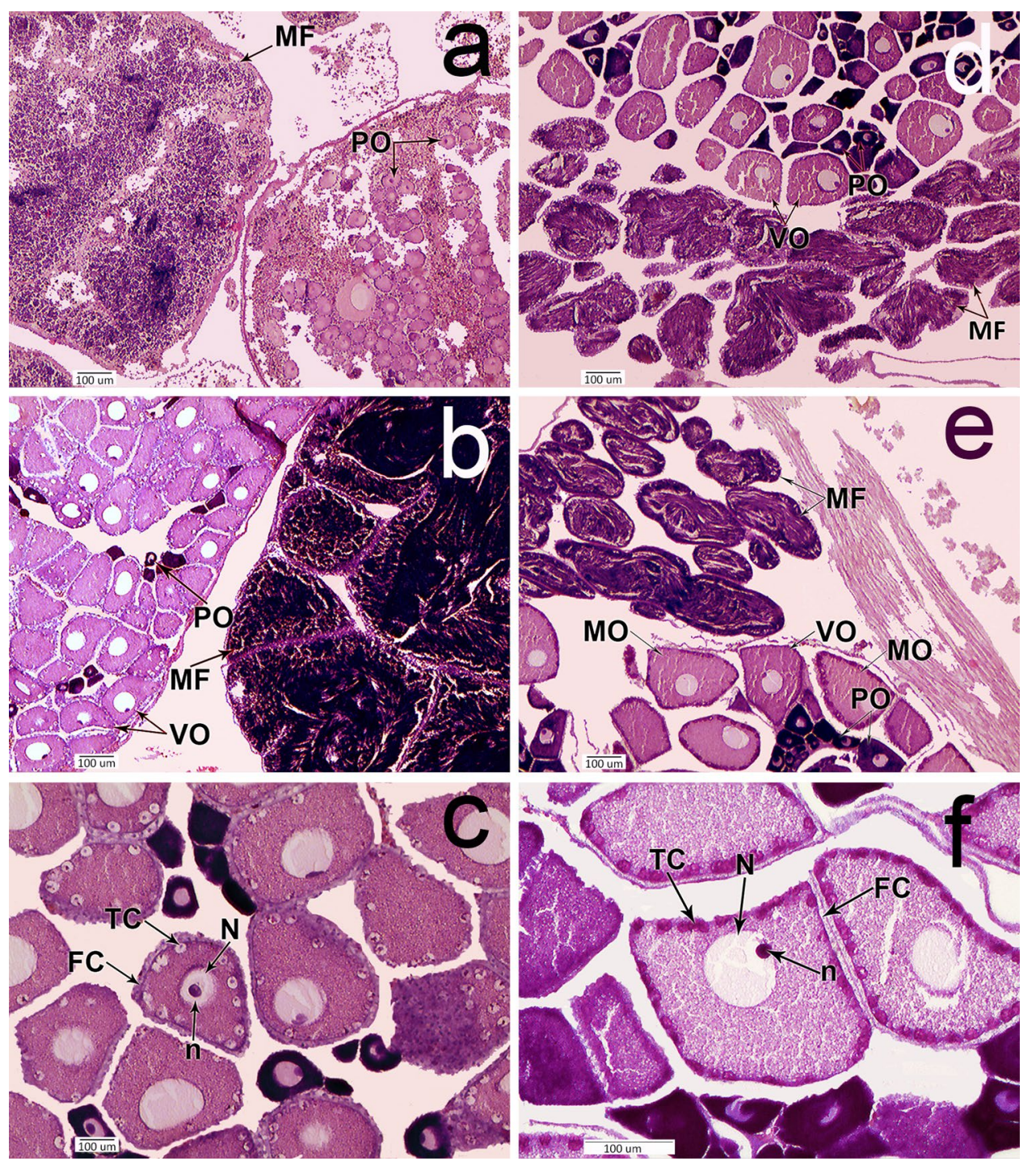


of male follicle development. Stage I: (immature)—male follicles replete with spermatocytes and some spermatozoa present in the lumen. Stage II:- spermatocytes located in the peripheral region of the male follicles while numerous spermatozoa were present in the lumen, with their heads oriented towards the cortex and their tails towards the central region of it; and stage III: (mature)-male follicles full with mature spermatozoa, with their heads oriented towards the cortex and their tails towards the central region (Online Resource 2 and 3). A maturity index (MI) for male gametes was calculated using the formula of Yoshida (1952):

$M I=\frac{\Sigma n F}{N}$,

where $F$ is the gametogenic stage (I-III in both species), $n$ is the number of organisms in stage $F$, and $N$ is the total number of sampled organisms ( $F$ was subjectively estimated see Sahade et al. 2004b).

To test whether there were significant variations in mean oocyte size, a nonparametric Kruskal-Wallis (K-W) variance test was performed due to the lack of variance homogeneity (Levene test) even after transformation. When medians were different, the multiple range test described by Conover (1999) was used to identify which months statistically differed.

\section{Results}

The histological examination of the gonads of $S$. rustica and $H$. pyriformis supported that both are hermaphrodites. In both species, the female gonadal portion is situated in the medullary position of the gonads, and the male follicles in the cortical portion; this distribution was maintained throughout the reproductive cycle.

\section{Styela rustica}

In $S$. rustica, oocytes $<80 \mu \mathrm{m}$ were immature and did not show any yolk (previtellogenic), oocytes between 80 and $160 \mu \mathrm{m}$ underwent vitellogenesis, and oocytes $>160 \mu \mathrm{m}$ were mature (Fig. 2). The maximum oocyte size $(243 \mu \mathrm{m})$ was observed in specimens sampled in August 2004 (Online Resource 4). Mean oocyte size varied significantly during the summer months.

Previtellogenic oocytes were present year-round, but in higher percentages in winter and spring. Vitellogenic oocytes were also present year-round but increased gradually from winter to the beginning of summer. Mature oocytes were observed during the summer months, peaking in August 2004 and July 2005 (Kruskal-Wallis test; $H=1546.88 ; p<0.0001$ ) (Table 1, Fig. 3).

In the male gonad portion, immature follicles (class I) were observed almost year-round until the beginning of spring, while, in the summer months, intermediate (class II) and mature (class III) follicles were present. This species showed simultaneous maturity of male and female gametes, and the maximum value in the Maturity Index (MI) coincided with the largest mean oocyte size during the summer months (Fig. 3).

\section{Halocynthia pyriformis}

In $H$. pyriformis, oocytes were larger than those of $S$. rustica for all stages and throughout the reproductive cycle. The oocytes $<150 \mu \mathrm{m}$ were previtellogenic, vitellogenesis started in oocytes between 150 and $250 \mu \mathrm{m}$, and oocytes $>250 \mu \mathrm{m}$ were mature. The maximum oocyte size observed was $406 \mu \mathrm{m}$ in June 2005 (Fig. 2) (Online Resource 4).

Oocyte class distribution showed a marked annual cycle, with an almost constant portion of previtellogenic and vitellogenic oocytes year-round. Mature oocytes were also present year-round, reaching a marked peak in June
Table 1 Non-parametric K-W test of oocyte Feret diameter differences among sampling dates in Styela rustica

\begin{tabular}{|c|c|c|c|c|c|c|c|c|c|c|}
\hline \multicolumn{6}{|l|}{ Month } & \multirow{2}{*}{$\frac{\text { Year }}{2005}$} & \multirow{2}{*}{$\frac{\text { Mean }}{63.18}$} & \multirow{2}{*}{$\frac{S d}{27.62}$} & \multirow{2}{*}{$\frac{\mathrm{H}}{1546.88}$} & \multirow{2}{*}{$\frac{p}{<0.0001}$} \\
\hline Jan & (A) & & & & & & & & & \\
\hline Mar & (A) & & & & & 2005 & 63.65 & 13.14 & & \\
\hline Apr & (A) & & & & & 2005 & 60.27 & 16.16 & & \\
\hline Jan & & (B) & & & & 2004 & 71.65 & 19.35 & & \\
\hline Nov & & (B) & & & & 2005 & 78.27 & 43.52 & & \\
\hline Oct & & & (C) & & & 2004 & 89.44 & 44.85 & & \\
\hline May & & & & (D) & & 2005 & 89.73 & 26.81 & & \\
\hline Jun & & & & (D) & & 2005 & 100.47 & 37.10 & & \\
\hline Jul & & & & & (E) & 2005 & 122.73 & 44.01 & & \\
\hline Aug & & & & & (E) & 2004 & 131.58 & 58.2 & & \\
\hline
\end{tabular}

A multiple range test (Conover) was used to identify which months were different. Different capital letters indicate significant differences $(p<0.0001)$ 
Fig. 3 Styela rustica. a Seasonality mean proportion of oocyte class at Kongsfjorden (Svalbard, Arctic). Bars represent means \pm SDs. Numbers indicate the number of samples analyzed per month $(N)$. b Synchronization in the development of male and female gametes during the period sampled. Bars represent means \pm SEs

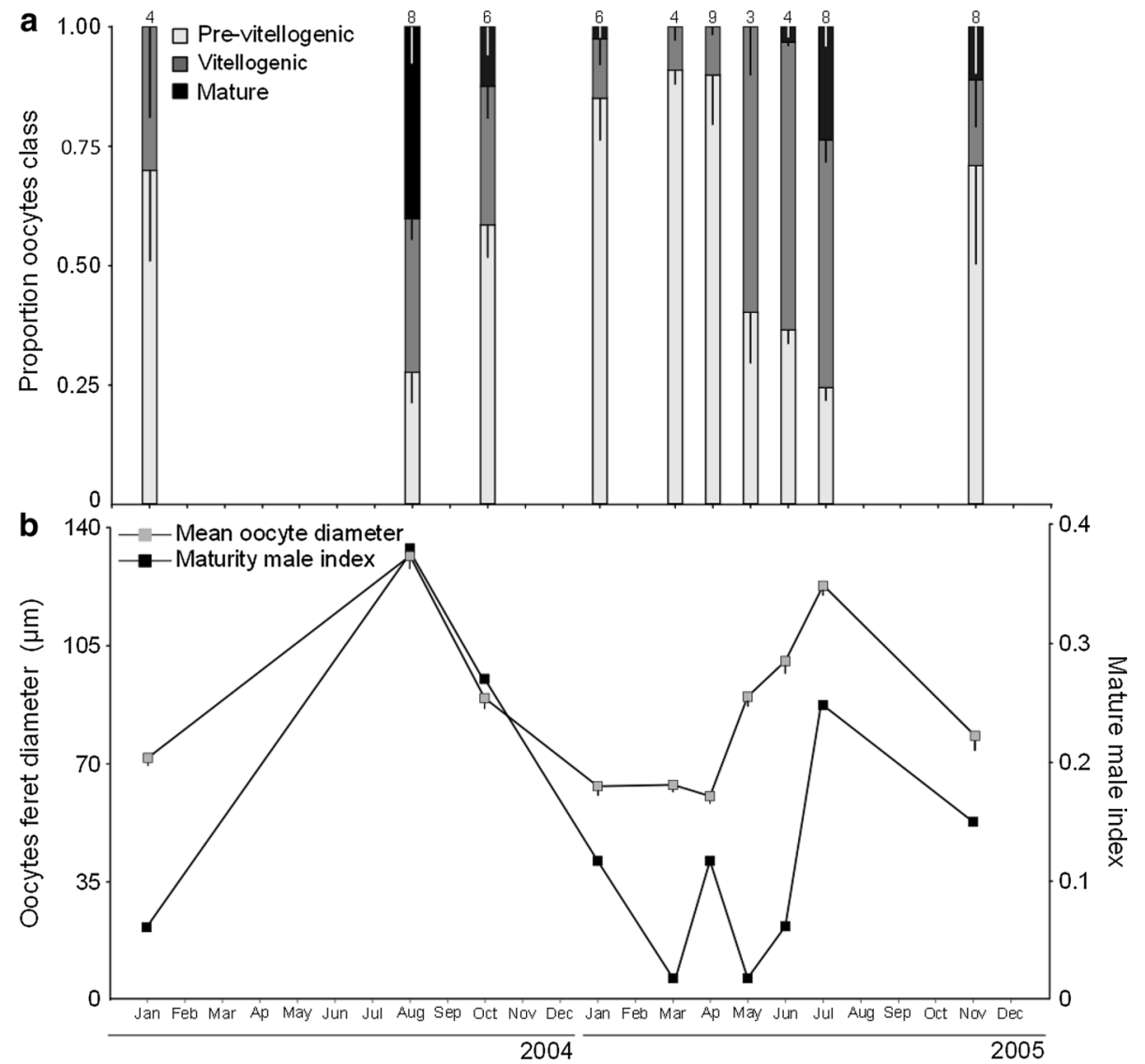

(Kruskal-Wallis test; $H=266.97 ; p<0.0001$ ) (Table 2, Fig. 4). The male gonad portion showed mature follicles (class III) almost year-round, peaking in June, while a month later in July, only intermediate follicles (class II) were observed. Immature follicles were scarce throughout the reproductive cycle.

Halocynthia pyriformis also showed simultaneous maturity of female and male gametes; however, this was mainly due to the almost permanent presence of mature follicles year-round. Despite this, the maturity index (MI) also showed variations along the reproductive cycle (Fig. 4).

\section{Discussion}

Notwithstanding their importance in Arctic benthic ecosystems (Sahade et al. 2004a; Beuchel and Gulliksen 2008), this is the first study, at least to our knowledge, closely
Table 2 Non-parametric K-W test of oocyte Feret diameter differences among sampling dates in Halocynthia pyriformis

\begin{tabular}{|c|c|c|c|c|c|c|c|c|c|c|}
\hline \multicolumn{6}{|l|}{ Month } & \multirow{2}{*}{$\frac{\text { Year }}{2005}$} & \multirow{2}{*}{$\frac{\text { Mean }}{113.14}$} & \multirow{2}{*}{$\frac{S d}{52.31}$} & \multirow{2}{*}{$\frac{\mathrm{H}}{266.97}$} & \multirow{2}{*}{$\frac{p}{<0.0001}$} \\
\hline Nov & (A) & & & & & & & & & \\
\hline Jul & & (B) & & & & 2005 & 122.67 & 49.32 & & \\
\hline Jan & & (B) & & & & 2005 & 130.94 & 58.64 & & \\
\hline Apr & & (B) & (C) & & & 2005 & 131.35 & 60.66 & & \\
\hline Oct & & (B) & (C) & (D) & & 2004 & 129.96 & 48.25 & & \\
\hline May & & (B) & (C) & (D) & & 2005 & 144.68 & 85.00 & & \\
\hline Mar & & & (C) & (D) & & 2005 & 137.51 & 60.34 & & \\
\hline Aug & & & & (D) & & 2004 & 134.30 & 47.56 & & \\
\hline Aug & & & & (D) & & 2005 & 137.39 & 45.59 & & \\
\hline Jun & & & & & (E) & 2005 & 184.37 & 80.03 & & \\
\hline
\end{tabular}

A multiple-range test (Conover) was used to identify which months were different. Different capital letters indicate significant differences $(p<0.0001)$ 
Fig. 4 Halocynthia pyriformis. a Seasonality mean proportion of oocyte class at Kongsfjorden (Svalbard, Arctic). Bars represent means \pm SDs. Numbers indicate the number of samples analyzed per month $(N)$. b Synchronization in the development of male and female gametes during the sampled period. Bars represent means \pm SEs

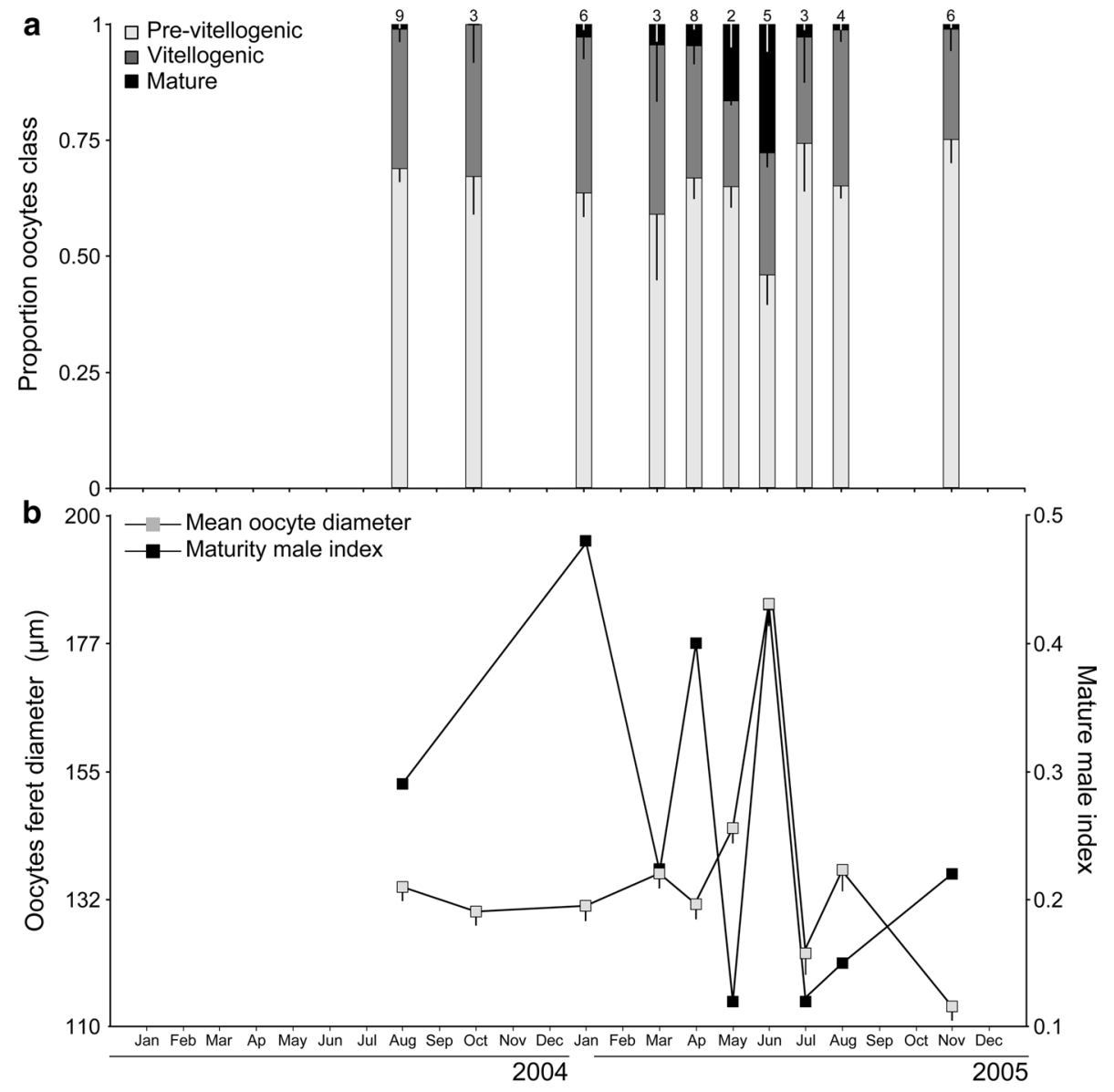

examining the reproductive biology, including gonadal analysis, of two ascidian species in the Arctic. The results indicate a single annual spawning event in both species but, despite belonging to a group with several common reproductive traits and living under the same environmental pressures, they exhibit different reproductive strategies in terms of seasonality, gamete maturation, and oocyte sizes. Styela rustica presented a reproductive peak during the summer (July-August), while H. pyriformis spawned slightly earlier in late spring.

Previous studies in S. rustica in Kruglaya Bay and Kandalaksha Bay (White Sea), located on the northwest coast of Russia $\left(66^{\circ} \mathrm{N}, 33^{\circ} \mathrm{E}\right)$, showed that they release their gametes in September (Khalaman et al. 2008). In this region, the spring diatom bloom occurs in mid-May, just after the ice break-up, and the temperature gradually rises from $1.7^{\circ} \mathrm{C}$ to $4 \pm 6{ }^{\circ} \mathrm{C}$ by the end of June. Styela rustica spawn their eggs when the energy available in this region is scarce but predation pressure is lower (Kosobokova 1999), similar to the strategies observed at Kongsfjorden. However, at the southernmost distribution limit of this species, in Kristineberg, Sweden $\left(58^{\circ} \mathrm{N}, 11^{\circ} \mathrm{E}\right)$, they apparently spawn in the colder period (from January until the middle of February) and decoupled of primary production pulses (Lützen 1960). On the Swedish west coast, surface water temperature varies throughout the year, with the lowest recorded temperatures February to March $\left(2-4{ }^{\circ} \mathrm{C}\right)$, the highest August to September $\left(15-17^{\circ} \mathrm{C}\right)$ (Arneborg 2004), and phytoplankton bloom occurs in spring (March-April) and autumn (August-September) (Gustafsson and Nordberg 2001). Therefore, contrary to the northern distribution limit, S. rustica seems to reproduce under colder months, and reproduction could be more related to cues such as water temperature changes, rather than to the primary production pulses characteristic of spring-summer seasons.

In the case of $H$. pyriformis, matching the present study, observations from the southwest coast of Iceland (Hvalfjordur, $64^{\circ} 21.8^{\prime} \mathrm{N} .21^{\circ} 29.7^{\prime} \mathrm{W}$ ) indicated that this species spawns in June and larvae may settle in autumn. Although this spawning period coincided with that observed in our work and is coupled with the primary production pulses of this region, spring bloom occurs in April, reaching maximum chlorophyll- $a$ (Chl- $a$ ) level in July $\left(6.0 \mathrm{mg} \mathrm{m}^{-3}\right.$ ) (Thorarinsdottir 1996). Svavarsson (1990) mentioned that $H$. pyriformis is a seasonal breeder and may have a pelagic larval stage of at least a couple of months, which would be striking, since solitary ascidians commonly present external fertilization and short larval periods of a couple of days, with 
a maximum of one week (Svane and Young 1989; Staver and Strathmann 2002; Strathmann et al. 2002, 2006; Thiyagarajan and Qian 2003; Khalaman et al. 2008). Moreover, we did not register any structural signs of brooding and larvae inside the bodies.

Maturation of oocytes and sperm was synchronous in $S$. rustica. Both female and male gametes showed the same maturation pattern, with peak mean oocyte sizes coinciding with higher values of the male gametes MI. The case of H. pyriformis was different: female gametes also showed a gradual development, but there were mature male gametes year-round and MI did not show a developmental pattern coupled with oocytes. This behavior resembles a slight protandry, as observed in other ascidian species (Manríquez and Castilla 2005; Rius et al. 2009; Wong et al. 2011). This pattern could be related to a strategy, characteristic of polar ecosystems invertebrates, to allocate more energy input to oocyte development, due to phytoplankton bloom. Instead, male gametes require less energy and may be maintained at less energy expense. Halocynthia pyriformis presented oocyte sizes that almost doubled those of $S$. rustica in each size class and in the observed maximum for each species $(H$. pyriformis: $406 \mu \mathrm{m}$, S. rustica: $243 \mu \mathrm{m})$. Halocynthia pyriformis oocytes were also larger than those reported in Antarctic ascidians and species distributed elsewhere, including Halocynthia hilgendorfi ritteri (220-260 $\mu \mathrm{m})$ from coastal waters of Jeju Island, Korea (Chen and Dai 1998; Sahade 1999; Sahade et al. 2004b; Carmack and Wassmann 2006; Rius et al. 2009; Wong et al. 2011; Pineda et al. 2013; Nagar and Shenkar 2016) (Online Resource 5). Despite that for a large number of marine invertebrates, offspring size is often correlated with maternal size, with larger mothers producing larger eggs than smaller mothers do (Marshall et al. 2000; Marshall and Keough 2003, 2007) it seems not to be the case in ascidian species where $H$. pyriformis oocytes doubled sizes even at much larger species like Molgula pedunculata and Cnemidocarpa verrucosa and many others including colonial forms (Becerro and Turon 1992; Manni et al. 1993; Bingham 1997; Sahade 1999; Sahade et al. 2004b; Rius et al. 2009 and pers obs.). Although larger-sized oocytes may be interpreted as a strategy for wider dispersal, as they contain higher energy reserves for the meroplanktonic, lecithotrophic larvae characteristic of ascidians, current data suggest the contrary, indicating that $H$. pyriformis presents populations with lower genetic diversity in Kongsfjorden than those of S. rustica (Demarchi et al. 2008; Demarchi 2013). This suggests a higher gene flow and dispersal potential among $S$. rustica populations compared to those of $H$. pyriformis.

An alternative explanation for the higher genetic structure and the rather larger egg size of $H$. pyriformis may be predation and the slight difference in spawning time of these two species. H. pyriformis spawns not only larger eggs but also slightly earlier in the rather short Arctic summer season. At that time, the abundance of planktonic predators is probably higher than during the spawning of $S$. rustica, in midsummer, since spring bloom in Kongsfjorden is subsequently slowed down by heavy grazing. Heterotrophic dinoflagellates, ciliates, larvaceans, and small and larger copepods are common at this period in the fjord (Hop et al. 2002). Thus, higher predation pressure on $H$. pyriformis larvae may diminish their dispersal potential as compared to $S$. rustica in Kongsfjorden.

Both species, S. rustica and H. pyriformis, showed reproductive seasonality coupled with the period of increased primary production, which is the expected pattern for polar filter feeders that depend directly on primary production rather than other feeding modes (Clarke 1996). In Kongsfjorden, due to light conditions, the spring bloom begins in late April with a considerable increase in phytoplankton biomass, from 20-25 mg Chl- $a \mathrm{~m}^{-2}$ (mean integrated data 0-50 m depth) in ice edge zones or under the ice to about $250 \mathrm{mg}$ Chl- $a$ $\mathrm{m}^{-2}$ in open waters during mid-May (Eilertsen et al. 1989; Hop et al. 2002).

Commonly, ascidians have a reproductive seasonality driven by temperature and primary production pulses. Species with temperate distribution show a yearly cycle with one spawning event, while tropical species can reproduce all year round (Durante and Sebens 1994; Lambert 2005; Ritzmann et al. 2009; Nagar and Shenkar 2016; Shmuel and Shenkar 2017). Indeed, some species with wide distribution ranges show both strategies, seasonal in temperate and continuous spawning in tropical populations. For instance, the reproductive cycle or settling patterns of Styela plicata have been determined for populations of Japan (Yamaguchi 1975), the eastern Mediterranean (Sabbadin 1957; Sciscioli et al. 1978; Tursi and Matarrese 1981), and the western Mediterranean (Pineda et al. 2013). These studies noted a decrease in reproductive activity during winter months and prolonged settlement during the summer, from June to September (Sciscioli et al. 1978), a more restricted summer settlement period, between August and September (Tursi and Matarrese 1981), a variable number of discrete generations per year (Sabbadin 1957; Yamaguchi 1975), or continuous potential spawning, with pulses of gamete release, especially in spring (Pineda et al. 2013). These differences in the reproductive cycle may be due to several factors, including water temperature, food availability, or daylight period (West and Lambert 1976). Thus, reproductive seasonality of ascidians seems to be driven rather by local extrinsic factors than by a fixed trait of each species.

Temperature and energy input are often closely linked in tropical and temperate areas, making it difficult to discriminate between these factors. Polar oceans, however, are characterized by rather constant temperatures, and highly seasonal pulses of energy input offer a good 
opportunity to assess the importance of each factor separately. The reproductive strategy of $S$. rustica and $H$. pyriformis, as we mentioned above, coincides with the high production period and is consistent with that idea. However, a contrasting pattern was reported from the Antarctic ascidian species, $C$. verrucosa and $M$. pedunculata, which also reproduce seasonally, but in the Antarctic winter. This was unexpected as energy is low during this period and energy reserves for further fuel reproduction were not reported (Sahade 1999; Sahade et al. 2004b). It could be due to the reduction of predation pressures on larvae, as predators are less abundant in winter. The strategy seems to be ecologically successful, since $C$. verrucosa and $M$. pedunculata are two of the most abundant ascidian species in Antarctica (Flores et al. 2012). This supports the idea that the slight differences in reproductive strategies between $H$. piriformis and $S$. rustica, seen in timing and egg sizes, could be related to predation pressure and be an important factor in shaping their population genetic structures.

This study is an important contribution to the scarce current knowledge on the reproductive strategies of marine invertebrates in the Arctic Ocean (Poltermann et al. 2000; Fetzer and Arntz 2008; Søreide et al. 2010; Kuklinski et al. 2013; Brandner et al. 2017). The reproductive traits and dynamics of polar benthic invertebrates are fundamental to understand these ecosystems and their resilience in the face of ongoing climate change.

Acknowledgements We would like to thank the SCUBA divers of AWI involved in sampling the species and installing the cages, namely Saskia Brandt, Daniel Carstensen, Wolfgang Nikolaus Probst, Bettina Saier, Philipp Schubert, Max Schwanitz, Christian Wecke, Ulrich Kunz, and José Velez. We are indebted to the station staff, Thorsten Wilhelm, Anne Hormes, Anne Theuerkauf, Jens Kuba and Kai Marholdt, as well as to Roland Neuber, who retrieved the cages and fixed the samples. We thank the three anonymous reviewers for their valuable suggestions. We are grateful for financial and logistic support provided by the Alfred Wegener Institute Helmholtz Centre for Polar and Marine Research (AWI), the Consejo Nacional de Investigaciones Científicas y Técnicas (CONICET), and the Secretaría de Ciencia y Tecnología (SECyT)

Funding This study was funded by the Alfred Wegener Institute Helmholtz Centre for Polar and Marine Research (AWI) and the Consejo Nacional de Investigaciones Científicas y Técnicas (CONICET). The work was partially funded by PICTO (Ref 36326 and 2010-0019) (ANPCyT-DNA) and the Secretaría de Ciencia y Tecnología (SECyT 05/I602).

\section{Compliance with ethical standards}

Conflict of interest The authors declare that they have no conflicts of interest.

Ethical approval All applicable international, national, and/or institutional guidelines for the care and use of animals were followed.
Informed consent (1) All authors agree to its submission and the corresponding author has been authorized by co-authors. (2) This article has not been published before and is not concurrently being considered for publication elsewhere. (3) This article does not violate any copyright or other personal proprietary right of any person or entity and it contains no abusive, defamatory, obscene, or fraudulent statements, nor any other statements that are unlawful in any way.

\section{References}

Arneborg L (2004) Turnover times for the waters above sill level in Gullmar Fjord. Cont Shelf Res 24:443-460. https://doi. org/10.1016/j.csr.2003.12.005

Azovsky A, Garlitska L, Chertoprud E (2016) Multi-scale taxonomic diversity of marine harpacticoids: does it differ at high and low latitudes? Mar Biol 163:1-12

Barnes D, Clarke A (1998) Seasonality of polypide recycling and sexual reproduction in some erect Antarctic bryozoans. Mar Biol 131:647-658. https://doi.org/10.1007/s002270050357

Becerro M, Turon X (1992) Reproductive cycles of the Ascidians Microcosmus sabatieri and Halocynthia papillosa in the Northwestern Mediterranean. Mar Ecol 13:363-373. https://doi. org/10.1111/j.1439-0485.1992.tb00360.x

Beszczyjska-Möller A, Weslawski JM, Walczowski W, Zajaczkowski M (1997) Estimation of glacial meltwater discharge into Svalbard coastal waters. Oceanologia 39(3)

Beuchel F, Gulliksen B (2008) Temporal patterns of benthic community development in an Arctic fjord (Kongsfjorden, Svalbard): results of a 24-year manipulation study. Polar Biol 31:913-924. https://doi.org/10.1007/s00300-008-0429-9

Bingham BL (1997) Light cycles and gametogenesis in three temperate ascidian species. Invertebr Biol 116:61-70. https://doi. org/10.2307/3226925

Bishop JDD, Ryland JS (1991) Storage of exogenous sperm by the compound ascidian Diplosoma listerianum. Mar Biol 108:111118. https://doi.org/10.1007/BF01313478

Brandner MM, Stübner E, Reed AJ, Gabrielsen TM, Thatje S (2017) Seasonality of bivalve larvae within a high Arctic fjord. Polar Biol 40:263-276. https://doi.org/10.1007/s00300-016-1950-x

Brockington S, Peck LS, Tyler PA (2007) Gametogenesis and gonad mass cycles in the common circumpolar Antarctic echinoid Sterechinus neumayeri. Mar Ecol Prog Ser 330:139-147. https://doi. org/10.3354/meps330139

Carmack E, Wassmann P (2006) Food webs and physical-biological coupling on pan-Arctic shelves: unifying concepts and comprehensive perspectives. Prog Oceanogr 71:446-477. https://doi. org/10.1016/j.pocean.2006.10.004

Chen YT, Dai CF (1998) Sexual reproduction of the Ascidian Polycarpa cryptocarpa kroboja from the Northern Coast of Taiwan. Acta Oceanogr Taiwan 37:201-210

Chiantore M, Cattaneo-Vietti R, Elia L, Guidetti M, Antonini M (2002) Reproduction and condition of the scallop Adamussium colbecki (Smith 1902), the sea-urchin Sterechinus neumayeri (Meissner 1900) and the sea-star Odontaster validus (Koehler 1911) at Terra Nova Bay (Ross Sea): different strategies related to inter-annual variations in food availability. Polar Biol 25:251-255. https://doi. org/10.1007/s00300-001-0331-1

Clarke A (1996) Benthic marine habitats in Antarctica. Antar Res Ser 70:123-133

Conover W (1999) Practical Nonparametric Statistics. John Wiley and Sons, New York

Demarchi M (2013) Genetic structure population of several species of ascidians (Tunicata, Ascidiacea) in two polar systems: south 
Shetland Islands, Antarctic and Kongsfjord, Spitsbergen, Arctic. Dissertation, Universidad Nacional de Córdoba

Demarchi M, Chiappero M, Laudien J, Sahade R (2008) Population genetic structure of the ascidian Styela rustica at Kongsfjorden, Svalbard, Arctic. J Exp Mar Biol Ecol 364:29-34. https://doi. org/10.1016/j.jembe.2008.06.022

Dunton K (1992) Arctic biogeography: the paradox of the marine benthic fauna and flora. Trends Ecol Evol 7:183-189. https:// doi.org/10.1016/0169-5347(92)90070-R

Durante KM, Sebens KP (1994) Reproductive ecology of the ascidians Molgula citrina (Alder \& Hancock, 1848) and Aplidium glabrum (Verrill, 1871) from the Gulf of Maine, U.S.A. Ophelia 39:1-21. https://doi.org/10.1080/00785326.1994.10429898

Eilertsen HC, Taasen JP, WesIawski JM (1989) Phytoplankton studies in the fjords of West Spitzbergen: physical environment and production in spring and summer. J Plankton Res 11:12451260. https://doi.org/10.1093/plankt/11.6.1245

Fetzer I, Arntz WE (2008) Reproductive strategies of benthic invertebrates in the Kara Sea (Russian Arctic): adaptation of reproduction modes to cold water. Mar Ecol Prog Ser 356:189-202. https://doi.org/10.3354/meps07271

Flores H, Atkinson A, Kawaguchi S et al (2012) Impact of climate change on Antarctic krill. Mar Ecol Prog Ser 458:1-19. https:// doi.org/10.3354/meps09831

Grange LJ, Tyler PA, Peck LS, Cornelius N (2004) Long-term interannual cycles of the gametogenic ecology of the Antarctic brittle star Ophionotus victoriae. Mar Ecol Prog Ser 278:141-155. https://doi.org/10.3354/meps278141

Grange LJ, Tyler PA, Peck LS (2007) Multi-year observations on the gametogenic ecology of the Antarctic seastar Odontaster validus. Mar Biol 153:15-23. https://doi.org/10.1007/s0022 7-011-1683-x

Grange LJ, Peck LS, Tyler PA (2011) Reproductive ecology of the circumpolar Antarctic nemertean Parborlasia corrugatus: no evidence for inter-annual variation. J Exp Mar Biol Ecol 404:98-107. https://doi.org/10.1016/j.jembe.2011.04.011

Gray JS (2001) Marine diversity: the paradigms in patterns of species richness examined. Sci Mar 65:41-56. https://doi.org/10.3989/ scimar.2001.65s 241

Gustafsson M, Nordberg K (2001) Living (stained) benthic foraminiferal response to primary production and hydrography in the deepest part of the Gullmar Fjord, Swedishwest coast, with comparisons to Hoglund's 1927 material. J Foraminifer Res 31:2-11. https://doi.org/10.2113/0310002

Hegseth EN, Tverberg V (2013) Effect of Atlantic water inflow on timing of the phytoplankton spring bloom in a high Arctic fjord (Kongsfjorden, Svalbard). J Mar Syst 113-114:94-105. https:// doi.org/10.1016/j.jmarsys.2013.01.003

Hop H, Pearson T, Hegseth EN et al (2002) The marine ecosystem of Kongsfjorden, Svalbard. Polar Res 21:167-208. https://doi. org/10.3402/polar.v21i1.6480

Jørgensen LL, Gulliksen B (2001) Rocky bottom fauna in Arctic Kongsfjord (Svalbard) studied by means of suction sampling and photography. Polar Biol 24:113-121. https://doi. org/10.1007/s003000000182

Kanamori M, Baba K, Natsuike M, Goshima S (2017) Life history traits and population dynamics of the invasive ascidian, Ascidiella aspersa, on cultured scallops in Funka Bay, Hokkaido, northern Japan. J Mar Biol Assoc 97:387-399. https://doi. org/10.1017/S0025315416000497

Khalaman VV, Belyaeva DV, Flyachinskaya LP (2008) Effect of excretory-secretory products of some fouling organisms on settling and metamorphosis of the larvae of Styela rustica (Ascidiae). Russ J Mar Biol 34:170-173. https://doi.org/10.1134/ S106307400803005X
Kosobokova KN (1999) The reproductive cycle and life history of the Arctic copepod Calanus glacialis in the White Sea. Polar Biol 22:254-263. https://doi.org/10.1007/s003000050418

Koziorowska K, Kuliński K, Pempkowiak J (2017) Distribution and origin of inorganic and organic carbon in the sediments of Kongsfjorden, Northwest Spitsbergen, European Arctic. Cont Shelf Res 150:27-35. https://doi.org/10.1016/j.csr.2017.08.023

Kuklinski P, Berge J, McFadden L, Dmoch K, Zajaczkowski M, Nygård H, Piwosz K, Tatarek A (2013) Seasonality of occurrence and recruitment of Arctic marine benthic invertebrate larvae in relation to environmental variables. Polar Biol 36:549-560. https:// doi.org/10.1007/s00300-012-1283-3

Lambert C, Brandt C (1967) The effect of light on the spawning of Ciona intestinalis. Biol Bull 132:222-228

Lambert CC (2009) Ascidian follicle cells: multifunctional adjuncts to maturation and development. Dev Growth Differ 51:677-686. https://doi.org/10.1111/j.1440-169X.2009.01127.x

Lambert CC, Lambert IM, Lambert G (1995) Brooding strategies in solitary ascidians: Corella species from north and south temperate waters. Can J Zool 73:1666-1671. https://doi.org/10.1139/ z95-198

Lambert G (2005) Ecology and natural history of the protochordates. Can J Zool 83:34-50. https://doi.org/10.1139/z04-156

Laudien J, Orchard JB (2012) The significance of depth and substratum incline for the structure of a hard-bottom sublittoral community in glacial Kongsfjorden (Svalbard, Arctic) an underwater imagery approach. Polar Biol 35:1057-1072. https://doi.org/10.1007/s0030 0-011-1153-4

Loeng H (1991) Features of the physical oceanographic conditions of the Barents Sea. Polar Res 10(1):5-18. https://doi.org/10.3402/ polar.v10i1.6723

Lützen J (1960) The reproductive cycle and the larval anatomy of the ascidian Styela rustica. Vidensk Meddr Dansk Naturh 123:227-236

Manni L, Zaniolo G, Burighel P (1993) Egg envelope cytodifferentiation in the colonial ascidian Botryllus schlosseri (Tunicata). Acta Zool 74:103-113. https://doi.org/10.1111/j.1463-6395.1993. tb01226.x

Manríquez PH, Castilla JC (2005) Self-fertilization as an alternative mode of reproduction in the solitary tunicate Pyura chilensis. Mar Ecol Prog Ser 305:113-125. https://doi.org/10.3354/meps305113

Manríquez PH, Guiñez R, Olivares A, Clarke M, Castilla JC (2018) Effects of inter-annual temperature variability, including ENSO and post-ENSO events, on reproductive traits in the tunicate Pyura praeputialis. Mar Biol Res 1:16. https://doi.org/10.1080/17451 000.2018 .1425456

Marshall DJ, Keough MJ (2003) Sources of variation in larval quality for free-spawning marine invertebrates: egg size and the local sperm environment. Invertebr Reprod Dev 44:63-70. https://doi. org/10.1080/07924259.2003.9652554

Marshall DJ, Keough MJ (2007) The evolutionary ecology of offspring size in marine invertebrates. Adv Mar Biol 53:1-60. https://doi. org/10.1016/S0065-2881(07)53001-4

Marshall DJ, Styan CA, Keough MJ (2000) Intraspecific co-variation between egg and body size affects fertilisation kinetics of freespawning marine invertebrates. Mar Ecol Prog Ser 195:305-309. https://doi.org/10.3354/meps195305

McBride MM, Dalpadado P, Drinkwater KF et al (2014) Krill, climate, and contrasting future scenarios for Arctic and Antarctic fisheries. ICES J Mar Sci 71:1934-1955. https://doi.org/10.1093/icesj $\mathrm{ms} / \mathrm{fsu} 002$

Millar RH (1971) The Biology of Ascidians. Adv Mar Biol 99:1-100. https://doi.org/10.1016/S0065-2881(08)60341-7

Nagar LR, Shenkar N (2016) Temperature and salinity sensitivity of the invasive ascidian Microcosmus exasperatus Heller, 1878. Aquat Invasions 11:33-43. https://doi.org/10.3391/ai.2016.11.1.04 
Nowak CA, Laudien J, Sahade R (2016) Rising temperatures and seaice-free winters affect the succession of Arctic macrozoobenthic soft-sediment communities (Kongsfjorden, Svalbard). Polar Biol 39:2097-2113. https://doi.org/10.1007/s00300-016-1995-x

Orejas C, López-González PJ, Gili JM, Teixidó N, Gutt J, Arntz WE (2002) Distribution and reproductive ecology of the Antarctic octocoral Ainigmaptilon antarcticum in the Weddell sea. Mar Ecol Prog Ser 231:101-114. https://doi.org/10.3354/meps231101

Pearse JS, Mcclintock JB, Bosch I (1991) Reproduction of Antarctic benthic marine invertebrates: tempos, modes, and timing. Am Zool 31:65-80. https://doi.org/10.1093/icb/31.1.65

Piepenburg D (2005) Recent research on Arctic benthos: common notions need to be revised. Polar Biol 28:733-755. https://doi. org/10.1007/s00300-005-0013-5

Pineda MC, López-Legentil S, Turon X (2013) Year-round reproduction in a seasonal sea: biological cycle of the introduced ascidian Styela plicata in the western Mediterranean. Mar Biol 160:221230. https://doi.org/10.1007/s00227-012-2082-7

Poltermann M, Hop H, Falk-Petersen S (2000) Life under Arctic sea ice-reproduction strategies of two sympagic (ice-associated) amphipod species, Gammarus wilkitzkii and Apherusa glacialis. Mar Biol 136:913-920. https://doi.org/10.1007/s002270000307

Ritzmann NF, Rocha RM, Roper JJ (2009) Sexual and asexual reproduction in Didemnum rodriguesi (Ascidiacea, Didemnidae). Iheringia Ser Zool 99:106-110. https://doi.org/10.1590/S0073-47212 009000100015

Rius M, Pineda MC, Turon X (2009) Population dynamics and life cycle of the introduced ascidian Microcosmus squamiger in the Mediterranean Sea. Biol Invasions 11:2181-2194. https://doi. org/10.1007/s10530-008-9375-2

Romeis B (1989) Mikroskopische Technik. Urban und Schwarzenberg, München

Sabbadin A (1957) Il ciclo biologico di Ciona intestinalis (L.), Molgula manhattensis (de Kay) e Styela plicata (Lesueur) nella laguna veneta. Arch Oceanogr Limnol 11:1-28

Sahade R (1999) Patterns and processes in an Antarctic epibenthic community: the case of Potter Cove. Dissertation, Universidad Nacional de Córdoba

Sahade R, Stellfeldt A, Tatián M, Laudien J (2004a) Macro-epibenthic communities and diversity of Arctic Kongsfjorden, Svalbard, in relation to depth and substrate. Ber Polarforsch Meeresforsch 492:103-111

Sahade R, Tatián M, Esnal G (2004b) Reproductive ecology of the ascidian Cnemidocarpa verrucosa at Potter Cove, South Shetland Islands, Antarctica. Mar Ecol Prog Ser 272:131-140. https://doi. org/10.3354/meps272131

Sciscioli M, Lepore E, Tursi A (1978) Relationship between Styela plicata (Les.) (Tunicata) settlement and spawning. Mem Biol Mar Oceanogr 8:65-75

Servetto N, Torre L, Sahade R (2013) Reproductive biology of the Antarctic "sea pen" Malacobelemnon daytoni (Octocorallia, Pennatulacea, Kophobelemnidae). Polar Res 32(1):20040. https://doi. org/10.3402/polar.v32i0.20040

Servetto N, Sahade R (2016) Reproductive seasonality of the Antarctic sea pen Malacobelemnon daytoni (Octocorallia, Pennatulacea, Kophobelemnidae). PLoS ONE 11:1-16. https://doi.org/10.1371/ journal.pone.0163152

Shenkar N (2012) Ascidian (Chordata, Ascidiacea) diversity in the Red Sea. Mar Biodivers 42:459-469. https://doi.org/10.1007/ s12526-012-0124-5

Shenkar N, Loya Y (2008) The solitary ascidian Herdmania momus: native (Red Sea) versus non-indigenous (Mediterranean) populations. Biol Invasions 10:1431-1439. https://doi.org/10.1007/s1053 0-008-9217-2
Shmuel Y, Shenkar N (2017) Reproductive cycle and ecology of the tropical ascidian Halocynthia spinosa in the Red Sea. Mar Biol 164:1-12. https://doi.org/10.1007/s00227-017-3179-9

Søreide JE, Leu E, Berge J, Graeve M, Falk-Petersen S (2010) Timing of blooms, algal food quality and Calanus glacialis reproduction and growth in a changing Arctic. Glob Chang Biol 16:3154-3163. https://doi.org/10.1111/j.1365-2486.2010.02175.x

Staver JM, Strathmann RR (2002) Evolution of fast development of planktonic embryos to early swimming. Biol Bull 203:58-69

Strathmann RR, Hughes TP, Kuris AM, Lindeman KC, Morgan SG, Pandolfi JM, Warner RR (2002) Evolution of local-recruitment and its consequences for marine populations. Bull Mar Sci 70:377-396

Strathmann RR, Kendall LR, Marsh AG (2006) Embryonic and larval development of a cold adapted Antarctic ascidian. Polar Biol 29:495-501. https://doi.org/10.1007/s00300-005-0080-7

Svane I, Young C (1989) The ecology and behaviour of ascidian larvae. Oceanogr Mar Biol 27:45-90

Svavarsson J (1990) Life cycle and population dynamics of the symbiotic copepod Lichomolgus canui Sars associated with the ascidian Halocynthia pyriformis (Rathke). J Exp Mar Biol Ecol 142:1-12. https://doi.org/10.1016/0022-0981(90)90133-W

Svendsen H, Beszczynska-møller A, Hagen JO et al (2002) The physical environment of Kongsfjorden-Krossfjorden, an Arctic fjord system in Svalbard. Polar Res 21:133-166. https://doi. org/10.3402/polar.v21i1.6479

Thiyagarajan V, Qian P (2003) Effect of temperature, salinity and delayed attachment on development of the solitary ascidian Styela plicata (Lesueur). J Exp Mar Biol Ecol 290:133-146. https://doi. org/10.1016/S0022-0981(03)00071-6

Thorarinsdottir GG (1996) Gonad development, larval settlement and growth of Mytilus edulis L. in a suspended population in Hvalfördur, south-west Iceland. Aquac Res 27(1):57-65

Tursi A, Matarrese A (1981) Phenomena of settling in Styela plicata (Les.) (Tunicata). Mem Biol Mar Oceanogr 11:117-130

Voronkov A, Hop H, Gulliksen B (2013) Diversity of hard-bottom fauna relative to environmental gradients in Kongsfjorden. Svalbard Polar Res 32:11208. https://doi.org/10.3402/polar.v32i0 .11208

Voronkov A, Hop H, Gulliksen B (2016) Zoobenthic communities on hard-bottom habitats in Kongsfjorden, Svalbard. Polar Biol 39:2077-2095. https://doi.org/10.1007/s00300-016-1935-9

West AB, Lambert CC (1976) Control of spawning in the tunicate Styela plicata by variations in a natural light regime. J Exp Zool 195:263-270. https://doi.org/10.1002/jez.1401950211

Wong NA, McClary D, Sewell MA (2011) The reproductive ecology of the invasive ascidian, Styela clava, in Auckland Harbour, New Zealand. Mar Biol 158:2775-2785. https://doi.org/10.1007/s0022 7-011-1776-6

Yamaguchi M (1975) Growth and reproductive cycles of the marine fouling ascidians Ciona intestinalis, Styela plicata, Botrylloides violaceus, and Leptoclinum mitsukurii at AburatsuboMoroiso Inlet (Central Japan). Mar Biol 29:253-259. https://doi. org/10.1007/BF00391851

Yoshida M (1952) Some observations on the maturation of the sea urchin, Diadema setosum. Annot Zool Jpn 25:265-271

Publisher's Note Springer Nature remains neutral with regard to jurisdictional claims in published maps and institutional affiliations. 